\title{
Effect of Planting Methods on the Yield and Yield Attributes of Short Duration Aman Rice
}

\author{
Md. Masud Rana ${ }^{{ }^{*}}$, Md. Abdullah Al Mamun', Afruz Zahan², Md. Nayeem Ahmed ${ }^{3}$, \\ Md. Abdul Jalil Mridha ${ }^{1}$ \\ ${ }^{1}$ Agronomy Division, Bangladesh Rice Research Institute, Gazipur, Bangladesh; ${ }^{2}$ Adaptive Research Division, Bangladesh \\ Rice Research Institute, Gazipur, Bangladesh; ${ }^{3}$ Soil Science Division, Bangladesh Rice Research Institute, Gazipur, Bangladesh. \\ Email: "
}

\begin{abstract}
Received November $19^{\text {th }}, 2013$; revised December $23^{\text {rd }}, 2013$; accepted January $11^{\text {th }}, 2014$
Copyright (C) 2014 Md. Masud Rana et al. This is an open access article distributed under the Creative Commons Attribution License, which permits unrestricted use, distribution, and reproduction in any medium, provided the original work is properly cited. In accordance of the Creative Commons Attribution License all Copyrights (c) 2014 are reserved for SCIRP and the owner of the intellectual property Md. Masud Rana et al. All Copyright (C) 2014 are guarded by law and by SCIRP as a guardian.
\end{abstract}

\section{ABSTRACT}

To find out the effect of planting methods on the yield and yield attributes of short duration Aman rice varieties, a field trial was conducted at the farm of Bangladesh Rice Research Institute, Gazipur, during July to November 2012. The treatments comprised of three BRRI released high yielding varieties viz., BRRI dhan39, BRRI dhan49 and BRRI dhan57 and three planting methods viz., direct seeding of dry seed, direct seeding of sprouted seed and transplanting. It was a factorial experiment conducted in a Randomized Complete Block Design with three replications. Planting methods had a significant effect on the growth duration of rice. The rice crop established with direct seeding of the dry and sprouted seed matured 7 days earlier than transplanting. The variety BRRI dhan39 gave the highest yield $\left(4.964 \mathrm{t}^{\circ} \mathrm{ha}^{-1}\right)$ when grown with direct seeding of sprouted seed compared to other varieties. The highest net return $\left(23362.00 \mathrm{BDT} \mathrm{ha}^{-1}\right)$ and cost benefit ratio $(1: 1.49)$ were observed in direct seeding of the sprouted seed method. So, direct seeding of sprouted seed might be the best planting method because about $19.94 \%$ production cost is reduced due to the omission of seedling raising and transplanting operations as well as the reduction in the length of the crop cultivation period.

\section{KEYWORDS}

\section{Direct Seeding of Dry and Sprouted Seed; Growth Duration; Short Duration Aman Rice}

\section{Introduction}

The people in Bangladesh depend on rice as staple food which has a tremendous influence on agrarian economy of Bangladesh. It has been feeding the region's population for well over 4000 years and is the staple food of about 557 million people [1]. Rice is grown in 11.53 million hectares of land with a production of 33.54 million tons where Aman rice covers the area of 5.64 million hectares with a production of 12.79 million tons of rice [2]. At present, rice cultivation is done in different ways in the world. The most important cultivation ways are direct seeding and transplanting methods. Rice cultivation in Bangladesh is predominantly practiced in transplanting method that involves raising, uprooting and

${ }^{*}$ Corresponding author. transplanting of seedlings. Transplanting is a resource and cost intensive method since the preparation of seedbed, the raising of seedling and the transplanting are labor- and time-intensive operations. Labor involvement for these operations consists of nearly one third of the total cost of the production in Bangladesh. To solve the problem of the labour shortage, alternate methods of rice stand establishment are inevitable. Direct seeding of rice is a potential alternate, which, is a successful method in various rice-growing countries of the world [3]. The final rice cultivation system in the world is affected by the water deficiency, the low suitable land, and shortages of worker [4]. Direct seeding of rice is the water- and labor-saving technique of cultivation [5]. It eliminates the need of seedling rising, maintaining and subsequent transplanting. In addition to higher economic returns, 
directly seeded crops are faster and easier to plant, less labor intensive and consume less water [6]. Directly seeded rice has received much attention all over the word by the agronomist because of its low-input demand. Therefore, the present study was designed to evaluate the effect of planting methods on the yield and yield attributes of short duration Aman rice varieties.

\section{Material and Methods}

The experiment was conducted at the farm of Bangladesh Rice Research Institute, Gazipur (90 $33^{\circ} \mathrm{E}$ longitude and $23^{\circ} 77^{\prime} \mathrm{N}$ latitude), during July to November 2012 to find out the effect of planting methods on the yield and yield attributes of short duration Aman rice varieties. Soil of the experimental field belongs to the Shallow Red Brown Terrace Soils. The region belongs to sub-tropical humid climate. The experiential soil characters are shown in Table 1 . The treatments comprised of three BRRI released high yielding varieties viz., BRRI dhan39, BRRI dhan49 and BRRI dhan57 and three planting methods viz.; direct seeding of dry seed, direct seeding of sprouted seed and transplanting. It was a factorial experiment conducted in a Randomized Complete Block Design with three replications. Layout of the experiment was done on 23 July 2012 with inter plot spacing of $1.0 \mathrm{~m}$ and inter block spacing of $1.0 \mathrm{~m}$. The size of each unit plot was $5.0 \mathrm{~m} \times$ $4.0 \mathrm{~m}$. Continuous line sowing of dry seed at $40 \mathrm{~kg} \cdot \mathrm{ha}^{-1}$ was done manually on 26 July 2012 with a line to line distance of $20 \mathrm{~cm}$ in the assigned plots when soil moisture was at field capacity. Seeds were immersed into water in a bucket on the same date of direct seeding of dry seed for 24 hours. These were then taken out of water and kept tightly in gunny bags. The seeds started sprouting after 48 hours which were suitable for sowing. The sprouted seeds were sown in line (line to line distance $20 \mathrm{~cm}$ ) in the assigned plots by manually on July 29 July 2012 and also sown in the nursery bed for raising seedling which was prepared previously. 25-day-old seedlings were transplanted (2 - 3 seedlings hill ${ }^{-1}$ ) on 23 August 2012 with a spacing of 20 $\mathrm{cm} \times 15 \mathrm{~cm}$. Light irrigation was applied $4-5$ days after seeding to facilitate germination and plant establishment, depending upon soil moisture in dry seeded plots. The experiment was conducted in rainfed condition but sup- plemental irrigation was applied as per necessary. The field was fertilized with urea, triple super phosphate, muriate of potash, gypsum and zinc sulphate at 127, 52, 82, 60 and $7 \mathrm{~kg} \cdot \mathrm{ha}^{-1}$, respectively. Except urea, whole amounts of other fertilizers were applied during final land preparation. Urea was top-dressed in three equal installments i.e., during sowing/transplanting, tillering stage and 7 days before panicle initiation. All agronomic practices were performed uniformly for all the treatments. Maturity of rice occurred at different times irrespective of planting method and variety. Harvesting was done from 25 October 2012 to 22 November 2012 depending upon the maturity of the three varieties. The harvested rice was then dried, threshed and cleaned and necessary data were collected. The collected data were compiled and tabulated for statistical analysis. Data were analyzed statistically for analysis of variance (ANOVA) following the method described by Gomez and Gomez [7]. MSTAT C computer software was used to carry out statistical analysis [8]. Partial economic analysis was done based on the prevailing market price.

\section{Results and Discussion}

\subsection{Tiller Production}

In this study, result showed that the number of effective tillers at harvest was not significant in different cultivars and cultivation methods (Table 2). The maximum number of effective tillers $\mathrm{m}^{-2}$ (232.667) was obtained from the direct seeding of sprouted seeds followed by the transplanting (230.333) and direct seeding of dry seed (202.215), respectively for BRRI dhan39 (Table 3). This might be due to the closer spacing of sprouted seeds which increased number of plants $\mathrm{m}^{-2}$. The result is supported by Ali [9] and Xiang et al., [10] who observed maximum number of effective tillers $\mathrm{m}^{-2}$ in the sprouted seeds than the seedlings transplanting method.

Table 1. Soil characters of the experimental site.

\begin{tabular}{cccccc}
\hline $\begin{array}{c}\text { Soil } \\
\text { texture }\end{array}$ & $\begin{array}{c}\text { Organic } \\
\text { matter }\end{array}$ & $\begin{array}{c}\text { Sand } \\
(\%)\end{array}$ & Silt (\%) & Clay (\%) & pH \\
\hline Loamy & 1.3 & 46 & 36 & 18 & 6.2 \\
\hline
\end{tabular}

Table 2. Effect of variety on the yield and yield attributes of short duration Aman rice.

\begin{tabular}{|c|c|c|c|c|c|}
\hline Variety & $\begin{array}{l}\text { Effective tillers } \\
\mathbf{m}^{-2}\end{array}$ & $\begin{array}{c}\text { Number of grains } \\
\text { panicle }^{-1}\end{array}$ & $\begin{array}{l}\text { 1000-grain weight } \\
\text { (g) }\end{array}$ & $\begin{array}{l}\text { Grain yield } \\
\left(\mathbf{t} \cdot \mathbf{h a}^{-1}\right)\end{array}$ & $\begin{array}{c}\text { Growth duration } \\
\text { (days) }\end{array}$ \\
\hline BRRI dhan39 & 221.738 & 139.172 & $20.601 a$ & $4.500 \mathrm{a}$ & $106.333 b$ \\
\hline BRRI dhan49 & 188.777 & 122.357 & 20.088a & $4.349 a$ & 115.333a \\
\hline BRRI dhan57 & 184.496 & 123.715 & $17.710 \mathrm{~b}$ & $3.587 b$ & $98.666 \mathrm{c}$ \\
\hline CV (\%) & 15.1 & 17.2 & 8.0 & 8.8 & 1.1 \\
\hline
\end{tabular}

Values of a column followed by same letter are statistically similar at 5\% probability. 
Table 3. Effect of interaction of variety and planting methods on the yield and yield attributes of short duration Aman rice.

\begin{tabular}{|c|c|c|c|c|c|}
\hline Interaction (Variety $\times$ planting method) & $\begin{array}{l}\text { Effective } \\
\text { tillers } \mathbf{~ m}^{-2}\end{array}$ & $\begin{array}{c}\text { Number of } \\
\text { grains panicle }^{-1}\end{array}$ & $\begin{array}{l}\text { 1000-grain } \\
\text { weight (g) }\end{array}$ & $\begin{array}{l}\text { Grain yield } \\
\left(\mathbf{t} \cdot \mathbf{h} \mathbf{a}^{-1}\right)\end{array}$ & $\begin{array}{c}\text { Growth } \\
\text { duration (days) }\end{array}$ \\
\hline BRRI dhan39 $\times$ Direct seeding of dry seed & 202.215 & 132.446 & 19.910 & 3.986 & $104.000 d$ \\
\hline BRRI dhan39 $\times$ Direct seeding of sprouted seed & 232.667 & 151.357 & 20.916 & 4.964 & $104.000 \mathrm{~d}$ \\
\hline BRRI dhan39 $\times$ Transplanting & 230.333 & 133.693 & 20.976 & 4.549 & $111.000 \mathrm{bc}$ \\
\hline BRRI dhan $49 \times$ Direct seeding of dry seed & 185.364 & 126.558 & 19.387 & 4.061 & $113.000 \mathrm{~b}$ \\
\hline BRRI dhan49 $\times$ Direct seeding of sprouted seed & 191.035 & 128.450 & 20.988 & 4.536 & $113.000 \mathrm{~b}$ \\
\hline BRRI dhan $49 \times$ Transplanting & 189.933 & 112.070 & 19.889 & 4.451 & $120.000 \mathrm{a}$ \\
\hline BRRI dhan57 $\times$ Direct seeding of dry seed & 181.551 & 103.718 & 18.179 & 3.316 & $93.000 \mathrm{e}$ \\
\hline BRRI dhan57 $\times$ Direct seeding of sprouted seed & 189.667 & 141.625 & 17.725 & 3.822 & $93.000 \mathrm{e}$ \\
\hline BRRI dhan57 × Transplanting & 182.272 & 125.801 & 17.226 & 3.622 & $110.00 \mathrm{c}$ \\
\hline CV (\%) & 15.1 & 17.2 & 8.0 & 8.8 & 1.1 \\
\hline
\end{tabular}

Values of a column followed by same letter are statistically similar at $5 \%$ probability.

\subsection{Number of Grains Panicle ${ }^{-1}$}

Investigation of grain number panicle ${ }^{-1}$ revealed that there was no significant difference between all forms of planting methods (Table 4). The direct seeding of sprouted seed produces the highest number of total grains panicle ${ }^{-1}$ (151.357) and the lowest number of grains panicle ${ }^{-1}$ (132.446) was recorded from the direct seeding of dry seed method for the variety BRRI dhan39. This might be attributed to better root development in direct seeding of sprouted seed which produced healthy panicles with higher number of grains. Nourbakhshian [11] and Yang et al., [12] found higher number of grains in sprouted seeds compared to that transplanting seedling.

\subsection{Thousand Grain Weight}

The thousand grain weight was not significantly affected by various planting methods. However, the thousand grain weight attained by the crop established through direct seeding of sprouted seed method was highest followed by transplanting and direct seeding of dry seed method (Table 4). The lowest grain weight was recorded from the crop established with direct seeding of dry seed. Awan et al., [13] reported lower grain weight in direct seeding of dry seed on flat soil than other planting methods of rice.

\subsection{Grain Yield}

There was significant difference in producing grain yield (Table 4). Direct seeding of sprouted seed method produced higher grain yield as compared to all other methods. The highest grain yield (4.964 $\mathrm{t} \cdot \mathrm{ha}^{-1}$ for BRRI dhan39) was recorded from direct seeding of sprouted seed (Table 3). Gupta et al., [14] reported 10\% higher yields in direct seeded rice than flooded transplanting. Higher yield in direct seeding of sprouted seed treatments are attributed to good crop conditions, more availability of nutrient which resulted higher tiller number, number of grains panicle ${ }^{-1}$ and 1000 -grain weight.

\subsection{Growth Duration}

Various cultivation methods significantly affected growth duration of the three rice varieties (Table 2). Establishment of rice with transplanting method needed the longest duration for maturity (120 days for BRRI dhan49). The rice crop grown with direct seeding of dry seed and sprouted seed matured 7 days earlier (113 days for BRRI dhan49) than that of the transplanting method (Table 4), agreeing with IRRI [15] study reports that depending on a cultivar, direct seeded rice matures seven to ten days earlier than transplanted rice. Growth duration of the crop was considerably reduced in direct seeded rice might be due to the absence of transplanting shock. The longer days to flowering and maturity in seedling transplanting could be due to longer period required for crop establishments compared to other methods.

\subsection{Economic Analysis}

\subsubsection{Total Variable Cost}

Variable cost varied due to the variation of crop establishment methods (Table 5). The highest variable cost was incurred by the transplanting method (59294.00 BDT ha ${ }^{-1}$ ) while the lowest variable cost was incurred by the direct seeding of dry seed method (46794.00 BDT $\mathrm{ha}^{-1}$ ). This was similar to the results of Kabir et al., [16] who found lowest variable cost in direct seeded rice due to the omission of seedling raising, uprooting and transplanting.

\subsubsection{Cost Benefit Ratio}

The cost benefit ratio of different rice planting methods is given in Table 6. The highest net return (23362.00 BDT ha ${ }^{-1}$ ) and cost benefit ratio (1:1.49) was noted in direct seeding of sprouted seed followed by direct seeding of dry seed and transplanting method, respectively. 
Table 4. Effect of planting methods on the yield and yield attributes of short duration Aman rice.

\begin{tabular}{|c|c|c|c|c|c|}
\hline Planting method & $\begin{array}{l}\text { Effective } \\
\text { tillers } \mathbf{~ m}^{-2}\end{array}$ & $\begin{array}{l}\text { Number of } \\
\text { grains panicle }^{-1}\end{array}$ & $\begin{array}{l}\text { 1000-grain } \\
\text { weight (g) }\end{array}$ & $\begin{array}{l}\text { Grain yield } \\
\left(t \cdot h^{-1}\right)\end{array}$ & $\begin{array}{c}\text { Growth } \\
\text { duration (days) }\end{array}$ \\
\hline Direct seeding of dry seed & 193.789 & 120.914 & 19.158 & $3.788 \mathrm{~b}$ & $103.000 \mathrm{~b}$ \\
\hline Direct seeding of sprouted seed & 204.456 & 140.477 & 19.876 & $4.441 \mathrm{a}$ & $103.000 \mathrm{~b}$ \\
\hline Transplanting & 200.846 & 123.855 & 19.364 & $4.207 a$ & $113.667 a$ \\
\hline CV (\%) & 15.1 & 17.2 & 8.0 & 8.8 & 1.1 \\
\hline
\end{tabular}

Values of a column followed by same letter are statistically similar at $5 \%$ probability.

Table 5. Total variable cost of rice under different planting methods.

\begin{tabular}{|c|c|c|c|c|c|c|c|}
\hline Planting Method & $\begin{array}{c}\text { Land preparation } \\
\left(\text { (BDT ha }^{-1}\right)\end{array}$ & $\begin{array}{l}\text { Irrigation } \\
(\text { BDT ha') }\end{array}$ & $\begin{array}{c}\text { Seed } \\
\left.(\text { BDT ha' })^{-1}\right)\end{array}$ & $\begin{array}{l}\text { Fertilizer } \\
\left(\text { BDT ha' } \text { ha }^{-1}\right.\end{array}$ & $\begin{array}{c}\text { Labor } \\
\left.(\text { BDT ha' })^{-1}\right)\end{array}$ & $\begin{array}{l}\text { Pesticide } \\
(\text { BDT hal) }\end{array}$ & $\begin{array}{c}\text { Total } \\
\left.(\text { BDT hat })^{-1}\right)\end{array}$ \\
\hline DS by dry seed & 4000 & 2000 & 1400 & 6894 & 31500 & 1000 & 46794 \\
\hline $\begin{array}{l}\text { DS by sprouted } \\
\text { seed }\end{array}$ & 4000 & 2000 & 1400 & 6894 & 32400 & 1000 & 47694 \\
\hline Transplanting & 5000 & 3000 & 1400 & 6894 & 42000 & 1000 & 59294 \\
\hline
\end{tabular}

DS = Direct seeding; Seed: $40 \mathrm{~kg} \cdot \mathrm{ha}^{-1}$ at $35 \mathrm{BDT} \mathrm{kg}{ }^{-1}$; Urea: $127 \mathrm{~kg} \cdot \mathrm{ha}^{-1}$ at BDT $20 \mathrm{~kg}^{-1}$; TSP: $52 \mathrm{~kg} \cdot \mathrm{ha}^{-1}$ at BDT $22 \mathrm{~kg}{ }^{-1}$; $\mathrm{MoP}^{-} 82 \mathrm{~kg} \cdot \mathrm{ha}^{-1}$ at BDT $15 \mathrm{~kg}{ }^{-1}$; Gypsum: $60 \mathrm{~kg} \cdot \mathrm{ha}^{-1}$ at BDT $12 \mathrm{~kg}^{-1}$; ZnSO 4 : $7 \mathrm{~kg} \cdot \mathrm{ha}^{-1}$ at BDT $180 \mathrm{~kg}^{-1}$; Labor wage: $300 \mathrm{BDT}^{-1}{ }^{-1}$; BDT = Bangladeshi currency.

Table 6. Cost benefit ratio as affected by different planting methods.

\begin{tabular}{|c|c|c|c|c|c|}
\hline Planting method & $\begin{array}{l}\text { Grain yield } \\
\qquad\left(t \cdot h^{-1}\right)\end{array}$ & $\begin{array}{l}\text { Total variable cost } \\
\left(\text { (BDT ha }^{-1}\right)\end{array}$ & $\begin{array}{l}\text { Gross return } \\
\left(\text { BDT ha }^{-1}\right)\end{array}$ & $\begin{array}{l}\text { Net return } \\
\left(\text { BDT ha }^{-1}\right)\end{array}$ & Cost benefit ratio \\
\hline & & $\mathrm{a}$ & $\mathrm{b}$ & $(b-a)$ & $(b-a)$ \\
\hline DS by sprouted seed & 4.44 & 47694.00 & 71056.00 & 23362.00 & 1.49 \\
\hline Transplanting & 4.21 & 59294.00 & 67433.00 & 8139.00 & 1.14 \\
\hline
\end{tabular}

DS = Direct seeding; Price: Rice grain $=$ BDT $16 \mathrm{~kg}^{-1}$.

The highest cost benefit ratio in direct seeding of sprouted seed method may be due to high yield, saving of irrigation water for puddling and labour charges beared for seedling raising and transplanting in the field. Sanjitha Rani and Jayakiran [17] had found higher net return in his experiment due to saving of labour cost and irrigation water in direct seeded rice.

\section{Conclusion}

It can be concluded from the results that variety BRRI dhan39 performed better than other varieties when grown with direct seeding of spouted seed method. Therefore, the cultivation of BRRI dhan39 with direct seeding of spouted seed method is recommended for better yield.

\section{REFERENCES}

[1] D. O. Manzanilla, T. R. Paris, G. V. Vergara, A. M. Ismail, S. Pandey, R. V. Labios, G. T. Tatlonghari, R. D. Acda and T. T. N. Chi, "Submergence Risks and Farmers' Preferences: Implications for Breeding Sub1 Rice in Southeast Asia,” Agricultural Systems, Vol. 104, 2011, pp. 335347. http://dx.doi.org/10.1016/j.agsy.2010.12.005

[2] BBS (Yearbook of Agricultural Statistics of Bangladesh),
Bangladesh Bureau of Statistics, Statistics Division, Ministry of Planning, Government of Bangladesh, Bangladesh, 2011, pp. 124-128.

[3] C. R. Adair, H. M. Beachell, N. E. Jodon, L. L. David and J. W. Jones, "Comparative Yields of Transplanted and Direct Sown Rice," Journal of the American Society of Agronomy, Vol. 34, No. 2, 1992, pp. 129-127. http://dx.doi.org/10.2134/agronj1942.0002196200340002 $\underline{0004 x}$

[4] N. V. Nguyen and A. Ferrero, "Meeting the Challenges of Global Rice Production," Paddy and Water Environment, Vol. 4, No. 1, 2006, pp. 1-9.

[5] G. Mahajan, V. Sardana, A. S. Brar and M. S. Gill, "Effect of Seed Rate, Irrigation Intervals and Weed Pressure on Productivity of Direct Seeded Rice (Oryza sativa L.)," Indian Journal of Agricultural Science, Vol. 76, No. 12, 2006, pp. 756-759.

[6] W. A. Jehangir, I. Masih, S. Ahmed, M. A. Gill, M. Ahmad, R. A. Mann, M. R. Chaudhary and H. Turral, "Sustaining Crop Water Productivity in Rice-Wheat Systems of South Asia: A Case Study from Punjab Pakistan," Draft Working Paper, International Water Management, Ins. Lahore, Pakistan, 2005.

[7] K. A. Gomez and A. A. Gomez, "Statistical Procedure for Agricultural Research,” 2nd Edition, International Rice Research Institute, John Wiley and Sons, New York, 
1994, pp. 1-340.

[8] B, Bricker, "MSTATC: A Micro-Computer Program for the Design, Management and Analysis of Agronomic Research Experimentation,” Department of Crop and Soil Sciences, Michigan State University, East Lansing, 1991.

[9] M. A. Ali, "Productivity and Resource-Use Efficiency of Rice as Affected by Crop Establishment and Nitrogen Management," Ph.D. Thesis, University of Los Banos, Los Banos, 2005.

[10] D. H. Xiang, F. R. Ying, L. Fang, X. H. Ding, R. Y. Fu and L. Fang, "A Study on Tiller Ear Bearing of Direct Seeded Rice for Yield up to 8.25 tha $^{-1}$," China Rice, Vol. 2, 1999, pp. 18-19.

[11] S. J. Nourbakhshian, "Function Comparison of Rice Varieties in Direct Seeded and Transplanting Methods," Iran Agricultural Science Journal, Vol. 2, No. 4, 2000, pp. 2532.

[12] S. U. Yang, Y. Sang, T. P. Sung, T. C. Byong, Y. Son, U. S. Yeo, S. T. Park and B. T. Chun, "Physiological and Yield Responses of Rice Cultivars in Direct Seeded and Transplanted Rice Cultivation," RDA Journal of Crop Science I, Vol. 40, No. 2, 1998, pp. 109-111.

[13] T. H. Awan, I. Ali, M. E. Safder, M. M. Ashraf and M.
Yaqub, "Economic Effect of Different Plant Establishment Techniques on Rice, Oryza sativa Production,” Journal of Agricultural Research, Vol. 45, No. 1, 2007, pp. 73-80.

[14] R. K. Gupta, R. K. Naresh, P. R. Hobbs, Z. Jiaguo and J. K. Ladha, "Sustainability of Post-Green Revolution Agriculture. The Rice-Wheat Cropping Systems of the IndoGangetic Plains and China,” In: Improving the Productivity and Sustainability of Rice-Wheat Systems: Issues and Impacts, ASA Special Publication 65, Washington DC, 2003, pp. 1-26.

[15] International Rice Research Institute (IRRI), "Rice Production Training Module: Method of Planting Rice," IRRI, Los Barios, 2008, pp.1-13.

[16] M. H. Kabir, M. S. U. Bhuiya, A. Saha, M. A. H. Khan and Nur-E-Elahi, "Effect of Crop Establishment Method and Time of Nitrogen Application on the Productivity of Boro Rice in Lowland Ecosystem," Bangladesh Rice Journal, Vol. 14, No. 1-2, 2009, pp. 1-6.

[17] T. S. Rani and K. Jayakiran, "Evaluation of Different Planting Techniques for Economic Feasibility in Rice,” Electronic Journal of Environmental Agricultural and Food Chemistry, Vol. 9, No. 1, 2010, pp. 150-153. 